\title{
NEW PHYTOTRON FOR STUDYING THE EFFECT OF CLIMATE CHANGE ON PLANT PATHOGENS
}

\author{
Maria Lodovica Gullino, Massimo Pugliese, Alessandro Paravicini, Enzo Casulli, \\ Andrea Rettori, Mattia Sanna, Angelo Garibaldi
}

\section{Introduction}

Global climate has changed since pre-industrial times, but in recent years the attention focused on this phenomenon has rapidly increased because of its economical, social and environmental consequences.

The scientific community largely holds anthropogenic emissions of carbon dioxide $\left(\mathrm{CO}_{2}\right)$ and other greenhouse gases responsible for the global climate system modification [Fuhrer 2003]. Indeed, on the basis of different greenhouse gas emission scenarios, the Intergovernmental Panel on Climate Change (IPCC) has concluded in its recent fourth assessment report that a change in global mean temperature of $0.6-$ $4^{\circ} \mathrm{C}$, in combination with changes in precipitation and an increased frequency of extreme weather events, is likely to occur until 2100 [IPCC 2007].

It seems clear that consequences for agriculture and forestry could be remarkable.

Even if temperature change is well within the limits of current climatic variability, a modest warming can cause significant increase in heat sums above a critical temperature threshold to affect crop physiology and resistance to disease [Chakraborty 2000]. In addition, changes in temperature, precipitation and the frequency of extreme events will influence disease epidemiology [Liu 2005; Matyssek 1999; Norby 1999; Curtis 1998; Marek 1995; Ceulemans 1994].

Changes in agricultural productivity can be the result of direct effects of these factors at the plant level, or indirect effects at the system level, for instance, through shifts in nutrient cycling, crop-weed interac-

\footnotetext{
Paper received 25.02.2009; accepted 15.12.2010
}

Maria lodovica Gullino, Massimo Pugliese, Enzo Casulli, Andrea Rettori, Mattia Sanna, Angelo Garibaldi: Centre of competence in the agro-environmental sector (AGROINNOVA) - University of Torino - Via L. da Vinci 44 - 10095 Grugliasco (TO), Italy.

Alessandro Paravicini: Tecno-El s.r.l. - Misure e Tecnologie

Elettroniche per l'Ambiente - Via degli Olmetti, 38 - 00060 Formello (Roma), Italy.

Corresponding Author: Pugliese Massimo, Tel. +390116708545, Fax +390116709307, e-mail: massimo.pugliese@unito.it tions, insect pest occurrence, and plant diseases [Garrett 2006].

Despite the paramount importance of plant disease for agricultural and natural ecosystems, little is known of how plant interactions with pathogens will change under future climatic conditions [McElrone 2005; Runion 2003; Percy 2002; Chakraborty 2000; Coakley 1999]

The expression of disease symptoms is influenced by three main components: (1) host, (2) pathogen, and (3) environmental conditions. Because plant predisposition to disease is altered by abiotic factors, changes in environmental variables such as elevated $\mathrm{CO}_{2}$ will also likely affect the severity and range of pathogens [Salinari 2006]. Understanding such relationships is vital to making predictions about overall plant health and for managing agricultural and natural ecosystems in the future.

The shortage of critical epidemiological data on individual plant diseases needs to be addressed using experimental approaches. In the first instance, studies in a controlled environment may be used to formulate hypotheses and to determine critical relationships to help develop process-based approaches. Field-based research examining the influence of a combination of interacting factors [Norby 1997; Senft 1995] would be needed to provide a more realistic appraisal of impacts.

A useful tool for such a type of study is phytotron, which can be defined as a closed greenhouse that can be used for the study of environmental conditions on plant growth and for plant gas production (consumption) monitoring.

Phytotrons permit to maintain precise control over environmental conditions (e.g. soil type, air temperature, relative humidity, light levels, carbon dioxide $\left(\mathrm{CO}_{2}\right)$ and ozone $\left(\mathrm{O}_{3}\right)$ concentration) and the organisms under study (e.g. mixtures of plant species and their spatial arrangement). Such a degree of rigor and control is virtually impossible to achieve under natural field conditions.

Phytotrons have been exploited to provide controlled and reproducible conditions for several types of studies in plant physiology and phenology [Nunn 
2005; Sasaki 2002; Grams 1999; Espigares 1993], plant biochemistry [Liu 2005; Gorissen 1995] agronomy [Tahir 2005; Harnos 1998], ecology [Dormann 2004], plant morphometry [Fukui 2004a; Fukui 2004b; Fukui 2004c; Kim 1995], food quality [Rosenfeld 1998] and plant pathology [Reignault 2001].

On the contrary, their use for studying climate change effects on pathosystems has not yet been fully exploited, in particular when $\mathrm{CO}_{2}$ level is considered. In this regard, phytotrons can play a key role in experimental research on global change by providing researchers with tools to aid in disentangling the complexities of natural ecosystems.

At present, at least in Europe, several kinds of phytotrons are already in use for studying the effect of environmental conditions and stresses on plant diseases, but in most cases experiments were carried out in small chambers, on seedlings or small plants, without monitoring and controlling carbon dioxide concentration and not specifically designed for studying plant-pathogens interactions, in particular on foliar diseases [Tani 1996; Thiel 1996; Uprety 1998; Schmadel-Hagebolling 1998; Gutierrez 2000; Grote 2001; Yazaki 2004; Cherukuri 2005; Luedemann 2005; Pritsch 2005]. Consequently, available phytotrons are not really suited to study the effect of climate change on plant disease or there is no scientific evidence of the possibility to use commercially available chambers for such purposes.

The aim of this paper is to describe in detail a new phytotron specifically developed for plant pathology studies, with particular attention to climate change effects, its possible constraints as well as reporting the results of the first experimental trials where the impact of variation in $\mathrm{CO}_{2}$ and temperature on Uncinula necatrix and Plasmopara viticola, two important pathogens of grapevine, has been assessed.

\section{General plant overwiew and phytotron technical features}

This phytotron has a volume of $10 \mathrm{~m}^{3}$ and its internal useable dimensions are $2 \times 2 \times 2.5 \mathrm{~m}(\mathrm{~W} \times \mathrm{L} \times \mathrm{H})$. The entrance door features a large glass window; the internal space is divided by a walkway into two parts, where two lots of 10 pots each can be set. Pots have a 151 capacity and their dimensions are $27 \times 27 \times 35$ $\mathrm{cm}$. Each pot series is placed in a PVC container located on a bench manually adjustable in height through a pressure cylinder. The ceiling above the pots is equipped with two lighting systems (Mastercolor CDM-TD metallic iodure discharge lamps and TLD Reflex 18/830 neon lamps Philips) a data acquisition system, supplied with I/O and RS 485 interfaces (CR1000 data logger, Campbell Scientific, U.S.A.), allows to manage the phytotron cycles and data collection.

Up to six phytotrons, connected by an RS485 network to a supervisor computer, were built (Fig. 1).

The internal space in the phytotron is divided in

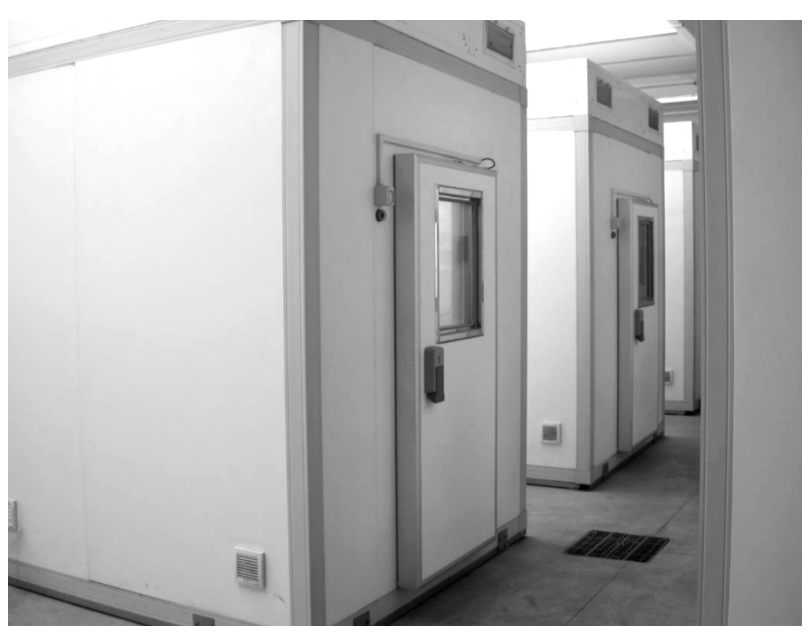

Fig. 1 - Two of the six phytotrons developed.

two sectors, in order to maintain as constant as possible the conditions above and below the ground, minimizing potential, negative interactions. Environmental parameters in each sector can be monitored, and maintained within a set range of variation.

The above-soil sector occupies most of the internal space and the specific environmental parameters measured and kept under control are the most affected by the climatic changes in progress.

Table 1 lists these parameters, showing their variation range and their maximum rate of change.

As for relative humidity, a minimum threshold of $25 \%$ at a temperature of $8^{\circ} \mathrm{C}$ was fixed to avoid temperature falling below the dew point in the dehumidifier exchanger. Lower temperatures would require very frequently de-icing cycles causing possible relative humidity overshoots.

Other parameters, such as air speed, leaf temperature and leaf wetness, are also measured and recorded in order to better characterize the inside environment.

In the pot containers, soil temperature and soil water content (absolute volumetric moisture content) can be monitored, the latter being used to activate the automatic irrigation system whenever a user-set threshold is reached.

Pots are housed in a sealed container and the separation between the above- and below-ground plant parts is achieved by a transparent PTE bag (Fig. 2).

Such a division is necessary to avoid that a very

\begin{tabular}{lll}
\hline Parameter & Variation Range & Maximum rate of change \\
\hline Air temperature & $8-40^{\circ} \mathrm{C}$ & $15^{\circ} \mathrm{C} / \mathrm{h}$ \\
Relative Humidity & $18-90 \%$ & $20 \% / \mathrm{h}$ \\
P.A.R & $0-1200 \mu \mathrm{mol} \mathrm{m}^{-2} \mathrm{~s}^{-1}$ & in three steps: $0,1 / 3,2 / 3,3 / 3$ \\
& & \\
$\mathrm{CO}_{2}$ concentration & $400-2000 \mathrm{ppm}$ & \\
\hline
\end{tabular}

TABLE 1 - Main environmental parameters monitored inside the phytotron together with their variation range and their maximum rate of change. 


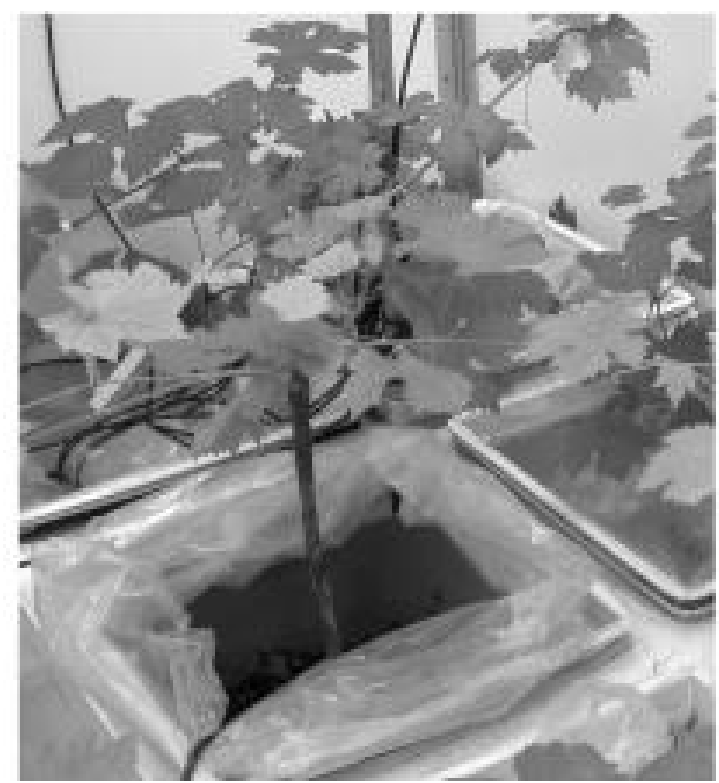

Fig. 2 - PTE hose useful to separate theepigeal from the hypogeal part of theplant. It shows how the epigeal part of the plant is separated from the hypogeal part.

high $\mathrm{CO}_{2}$ concentration inside the potting medium may influence air $\mathrm{CO}_{2}$ concentration, preventing an exact carbon balance determination. Moreover, by running cycles at low air relative humidity values, the pot medium could dry quickly requiring very frequent irrigation cycles.

A series of water traps are placed on the bottom of the container to collect water in a large bottle outside the phytotron. This keeps pot percolation water from stagnating on the container floor. An air circulation system exchanges continuously the inside air at a rate set by an electronic speed regulator, reducing the risk of moulds developing.

\subsection{Air temperature and relative humidity control system (ATU Air Treatment Unit)}

Two sections form the ATU: the first provides temperature control, while the second allows to monitor relative humidity. To control temperature, the air is blown through a heat exchanger (THW11.00, Biemme S.a.s, Italy) by an electric fan. In the heat exchanger a pump circulates a glycol solution whose temperature can either be raised or reduced by a resistor series or a freezing coil. Both these elements are installed inside the glycol volume tank.

The cooling system employs an air condenser and an electric compressor. It also provides, through another coil, air dehumidification through water vapor condensation. An ultrasonic humidifier is used to increase the relative humidity. The water used by the system is derived from the public water network after passing through a deionizer and a demineralizer unit.

Temperature and humidity control is performed via two electronic regulators whose set- point values are set by the software running on the supervisoring com- puter. The temperature and humidity transducers are located inside the ventilation duct.

\subsection{Lighting control system}

The lighting system is provided with two different light sources to obtain the best spectrum for plant growth. The lights used are: Gas discharge lamp type Philips CDM-TD $150 \mathrm{~W} / 942$ and Neon lamp type Philips Tl-D reflex 18W/830. Both lamps' emission spectra are available, respectively, at: http://www.ecat. lighting.philips.com/l/catalog/catalog.jsp?userLanguage $=$ en\&userCountry $=$ gb\&catalogType $=$ LP $P R O F$ ATG\& dyncharset=UTF-8\&categoryid $=$ LP CF DCDMTD EU FA GB LP PROF ATG\&productid=928084805133_EU_GB\&title=MASTERColour\%20CDM-TD\%20150W/942\%20RX7s\% 201CT\&ctn=928084805133 EU and http://www.ecat. lighting.philips.com/l/catalog/catalog.jsp?userLanguage $=$ en \&userCountry $=$ gb\&catalogType $=$ LP PROF ATG\& dyncharset=UTF-8\&categoryid=LP CF TLDR8ECO EU FA GB LP PROF ATG\&produc$\underline{\text { tid}}=928048183079$ EU GB\&title=MASTER\%20TLD\%20Reflex\%2018W/830\%201SL\&ctn $=9280481830$ $\underline{79 \mathrm{EU}}$. To maximize the light flux, all lamps are equipped with a reflecting shield. In particular, the neon lamps are a "reflex" type, meaning that they have an internal upper reflecting shield.

The lamp housing is separated from the space inside the phytotron by two hinged plexiglass doors, to make lamp replacement easy and to reduce temperature influence inside the chamber.

The lamps are electrically connected into three different groups allowing to obtain four different lighting levels: $0-1 / 3-2 / 3-3 / 3$.

Moreover, it is possible to adjust the light flux just by changing the pot container height and setting plants at different distances from the light source.

The lighting system is fully managed in automatic mode by the supervisoring computer.

PAR (Photosynthetically Active Radiation) can be monitored by a 400-700 $\mathrm{nm}$ radiation transducer (SKP-215, Skye Instruments, U.K.) positioned on top of a telescopic stand to allow placing it anywhere on the pot container.

The lamps are located below the ceiling of the phytotron, where two centrifugal electric cooling fans ensure air circulation.

To avoid dangerous overheating, two air temperature sensors are placed in the lamp compartment; the control system turns the lights off whenever the temperature exceeds $70^{\circ} \mathrm{C}$.

\section{$2.3 \mathrm{CO}_{2}$ concentration control system}

$\mathrm{CO}_{2}$ concentration is monitored and measured by a non dispersive infrared gas analyzer (GMW21D, Vaisala, Finland) situated on the rear wall, at $1.5 \mathrm{~m}$ height, giving the concentration mean value surrounding the plants. 
When it is necessary to increase the concentration, the control system operates a solenoid valve allowing the entry of a minimum quantity of $\mathrm{CO}_{2}$ in the phytotron ventilation duct. The solenoid valve opening / closing time is obtained by means of an optimized algorithm to avoid large oscillations of $\mathrm{CO}_{2}$ concentration values. The same algorithm manages the decrease of the concentration value, carried out by two motorized $(1 / 2)$ valves installed on the ventilation system input and output. In this way, the external air, having a $\mathrm{CO}_{2}$ concentration of about $400-500 \mathrm{ppm}$, is continuously mixed in small quantities with the inside air, decreasing the mean value. As the external air is the air of the laboratory the phytotron is situated in, it could be necessary to carry out a ventilation system to allow air exchange between the laboratory and the outside.

Great attention was paid to assure good insulation between the internal and external phytotron environments. This aim was achieved thanks to special neoprene washers for the door, the frame panel joints and the plexiglass lamp doors. Special, solvent-free resins were used to seal hermetically all possible air leaks. Once the phytotron was placed in the laboratory, the inside $\mathrm{CO}_{2}$ concentration was increased to a very high level $(2000 \mathrm{ppm})$. Then, all the frame joints were tested using a high speed $\mathrm{CO}_{2}$ analyzer and, if necessary, sealed again.

The same method was employed to assess pot container sealing.

\subsection{Data acquisition and control system (DACS)}

The DACS use a CR1000 a Campbell Scientific data logger to acquire, process and store data. It is equipped with an input/output interface and a serial RS485 type interface. This configuration allows a connection between phytotrons and the supervising computer through a local network.

The DACS provides the following tasks:

a) data acquisition, processing and storage;

b) control of temperature and relative humidity regulator program cycles;

c) running and monitoring the lighting system cycles;

d) management of cycles set up for the $\mathrm{CO}_{2}$ concentration control system;

e) management of all the alarm conditions;

f) administration of the RS 485 local network interface.

Connection to DACS is possible not only through the RS485 network but also through a local PC connected by another port, RS232 type, available on the CR1000 unit.

The software running on the supervisor computer allows to: (i) communicate with the six remote DACS units; (ii) set the operating cycles and alarm thresholds; (iii) receive and display all measured values together with the cycles status .

The user can start and stop any cycle, on any phytotron, simply using a Plant Synoptic software.

\section{Phytotron operation cycle and testing results}

The operation cycle is usually programmed by the supervisor computer, but it can also be controlled by a local computer RS 232 connected to the phytotron. The operation cycle running on the DACS can be started and stopped through manual commands and consists of 24 hourly segments synchronized by the CR 1000 internal real time clock. For each hourly segment, it is possible to set the following parameter values:

- air temperature, from 8 up to $40^{\circ} \mathrm{C}$;

- air relative humidity, from $18 \%$ up to $90 \%$ (with a minimum of $25 \%$ at the temperature of $8^{\circ} \mathrm{C}$ );

- $\mathrm{CO}_{2}$ concentration, from $400-500$ up to $2000 \mathrm{ppm}$;

- lighting, from 0 up to $1200 \mu \mathrm{mol} \mathrm{m}^{-2} \mathrm{~s}^{-1}$ in four steps $(0-1 / 3-2 / 3-3 / 3)$.

Once programmed and set in "start" mode, the operation cycle runs continuously until the user passes to "stop" mode.

In addition to the parameters mentioned above, DACS measures and stores the following parameters with a sampling time set at $5 \mathrm{~s}$ :

- Leaf temperature (2 sensors)

- P.A.R

- Air speed

- Leaf wetness

- Soil temperature (two sensors)

- Soil water content (two sensors)

The CR 1000 provides both the signals' digital filtering and measure validation.

After a suitable testing period on a phytotron prototype, several operation cycles were performed in order to assess the control system's stability and to optimize the management of all systems involved. Analysis of collected data shows that the oscillation values were very close to the set point for each controlled parameters.

In particular, the oscillation values pointed out are:

- Air Temperature $:+/-0.2^{\circ} \mathrm{C}$

- Air relative humidity : $+/-2 \%$

- $\mathrm{CO}_{2}$ concentration : + / - $30 \mathrm{ppm}$

Obviously, larger oscillations were detected during the opening time of the two motorized valves used to mix inside with outside air. This fact is due to the different temperature and humidity values of the two mixed airs.

In order to overcome this problem, a phytotron plant implementation is being taken into account. The working hypothesis is to use an air pre-conditioning system that should be able to supply the six phytotrons with air at mean temperature and humidity values (i.e $18^{\circ} \mathrm{C}, 50 \%$ ).

The system could also be improved with a chemical cell system to decrease the $\mathrm{CO}_{2}$ concentration. In this way it could be possible to operate with inside concentration values lower than $400 \mathrm{ppm}$.

Good results were obtained with the air circulation system installed in the pot container. In fact, operating the manual air speed control, good and stable thermo- 
hygrometrical conditions were achieved, not only ensuring a right substratum water evaporation, but also avoiding rot or mould proliferations.

\section{First experimental trials}

\subsection{Materials and methods}

The aim of this experimental activity was to study the impact of climatic condition variation on two important pathogens of grapevines: powdery and downy mildew. The attention was focused on temperature and $\mathrm{CO}_{2}$ concentration, important factors for plant growth processes and disease organism development.

The main phytotron's features were exploited to simulate three different environmental conditions as described in Table 2.

The "Ambient" condition has to be considered the reference point, since it reproduces values of temperature and relative humidity detectable at the end of spring in Piedmont, when primary infections occur.

The "Elevated $\mathrm{CO}_{2}$ " condition was set up for evaluating the effect of high $\mathrm{CO}_{2}$ concentrations on plant growth and pathogen epidemic.

Finally the "Elevated $\mathrm{T}$ and $\mathrm{CO}_{2}$ " condition aims to mimic one of the most extreme IPCC climate change scenarios, predicting an increase in temperature of $4{ }^{\circ} \mathrm{C}$ and in $\mathrm{CO}_{2}$ concentration of $100 \%$ over the next 100 years [IPCC 2007].

Inside each phytotron, five "Moscato" and five "Barbera" potted grapevines were placed when powdery mildew was assessed or five "Nebbiolo" and five "Barbera" potted grapevines were placed for assessing downy mildew. In order to allow a good adaptation to the artificial environment all plants were allowed to grow in an "Ambient" condition for ten days. At the end they were inoculated with a conidial suspension concentration of $1 \times 10^{5} \mathrm{CFU} / \mathrm{ml}$ of pathogens and environmental parameters inside the phytotrons were changed according to the scheme reported in Table 2.

Two trials were carried out for each pathosystem. Disease assessment was carried out every seven days, visually evaluating the percentage of leaf area infected (severity) and the percentage of leaves infected (incidence). Trials were considered concluded when mildews growth stopped.

In order to both exploit all the six climatic chambers available and have a larger sample number, each trial was carried out setting up the same environmental condition in two different phytotrons.

A statistical data analysis was performed with SPSS17.0 for Windows, using an analysis of variance, Student-Newman-Keuls post hoc test, Kruskal-Wallis non-parametric test and Levene's test for homogeneity of variance. According to convention, the level of significance was set to a $p$ value of 0.05 . Significance levels of 0.05 or lower are marked with an asterisk $(*)$.

\subsection{Technical aspects and constraints}

A small-quantity constant ventilation was detected and showed to positively affect the development of powdery mildew, that also infested naturally the plants. On the contrary, this ventilation system showed not to favour the infections of downy mildew and it prevented the formation of a thin layer of water on the leaf surface that is necessary for disease development. In order to overcome this problem, plastic films were used to create removable tunnels inside the phytotrons and they were used to increase air humidity and in particular to keep a thin layer of water on the leaf's surface, avoiding at the same time mould proliferations.

\subsection{Results and discussion}

\subsubsection{Powdery mildew}

The second trial confirmed the results observed during the first one. Results reported in both Figures 3 and 4 and the subsequent data analysis refers to the first trial.

The analysis of variance shows differences between environmental conditions in both severity (mean percentage of leaf area infected) and incidence (mean percentage of leaves infected) of powdery mildew infection. No differences between cultivar

\begin{tabular}{|c|c|c|c|c|c|c|}
\hline \multirow{2}{*}{ Phytotron } & \multicolumn{2}{|c|}{ Temperature } & \multirow{2}{*}{$\mathrm{CO}_{2}$} & \multicolumn{2}{|c|}{ Relative humidity } & \multirow{2}{*}{ Condition } \\
\hline & $\begin{array}{l}\text { Powdery } \\
\text { mildew }\end{array}$ & Downy mildew & & $\begin{array}{l}\text { Powdery } \\
\text { mildew }\end{array}$ & $\begin{array}{l}\text { Downy } \\
\text { mildew }\end{array}$ & \\
\hline 1 & $\begin{array}{c}\text { from } 22^{\circ} \mathrm{C} \text { to } \\
30^{\circ} \mathrm{C}\end{array}$ & $\begin{array}{c}\text { from } 24^{\circ} \mathrm{C} \text { to } \\
26^{\circ} \mathrm{C}\end{array}$ & 800ppm & $\begin{array}{c}\text { from } 40 \% \text { to } \\
85 \%\end{array}$ & $\sim 90 \%$ & Elevated $\mathrm{T}$ and $\mathrm{CO}_{2}$ \\
\hline 2 & $\begin{array}{l}\text { from } 18^{\circ} \mathrm{C} \text { to } \\
\qquad 26^{\circ} \mathrm{C}\end{array}$ & $\begin{array}{l}\text { from } 20^{\circ} \mathrm{C} \text { to } \\
22^{\circ} \mathrm{C}\end{array}$ & 800ppm & $\begin{array}{c}\text { from } 40 \% \text { to } \\
85 \%\end{array}$ & $\sim 90 \%$ & Elevated $\mathrm{CO}_{2}$ \\
\hline 3 & $\begin{array}{l}\text { from } 18^{\circ} \mathrm{C} \text { to } \\
\qquad 26^{\circ} \mathrm{C}\end{array}$ & $\begin{array}{l}\text { from } 20^{\circ} \mathrm{C} \text { to } \\
22^{\circ} \mathrm{C}\end{array}$ & 450ppm & $\begin{array}{c}\text { from } 40 \% \text { to } \\
85 \%\end{array}$ & $\sim 90 \%$ & Ambient \\
\hline
\end{tabular}




\begin{tabular}{|c|c|c|c|c|c|}
\hline Source & Type III Sum of Squares & df & Mean Square & $\mathbf{F}$ & Sig. \\
\hline Corrected Model & 1025.829 & 5 & 205.166 & 5.127 & .001 \\
\hline Intercept & 10140.574 & 1 & 10140.574 & 253.398 & .000 \\
\hline Phytotron & 942.547 & 2 & 471.273 & 11.776 & $.000 *$ \\
\hline Cultivar & 32.887 & 1 & 32.887 & .822 & .369 \\
\hline Phytotron * Cultivar & 50.396 & 2 & 25.198 & .630 & .537 \\
\hline Error & 1920.882 & 48 & 40.018 & & \\
\hline Total & 13087.285 & 54 & & & \\
\hline Corrected Total & 2946.712 & 53 & & & \\
\hline
\end{tabular}

TABLE 3 - Analysis of variance results for powdery mildew infection severity.

were detected (Tab. 3 and 4). Levene's test showed that the assumption about homogeneity of error variances among groups is violated for this variable. Thus, the Kruskal-Wallis test was used to confirm the analysis of variance results (Tab. 5). In order to understand how environmental conditions could affect pathogen development a Student-Newman-Keuls was applied to find out differences between data coming from differently set-up phytotrons (Tab. 6 and 7).
A combination of increasing temperature and carbon dioxide concentration reduce both severity and incidence. On the contrary, disease infection in "Elevated $\mathrm{CO}_{2}$ " is similar to the "Ambient" environmental condition without any difference. It seems that plants in "Elevated $\mathrm{T}$ and $\mathrm{CO}_{2}$ " conditions were more disease-resistant thanks to the fact that they were carbon dioxide fertilized in better environmental conditions than the other ambient.

\begin{tabular}{|c|c|c|c|c|c|}
\hline Source & Type III Sum of Squares & df & Mean Square & $\mathbf{F}$ & Sig. \\
\hline Corrected Model & 13337.492 & 5 & 2667.498 & 8.258 & .000 \\
\hline Intercept & 250859.901 & 1 & 250859.901 & 776.621 & .000 \\
\hline Phytotron & 12775.419 & 2 & 6387.710 & 19.775 & $.000 *$ \\
\hline Cultivar & 1.112 & 1 & 1.112 & .003 & .953 \\
\hline Phytotron * Cultivar & 560.961 & 2 & 280.480 & .868 & .426 \\
\hline Error & 15504.695 & 48 & 323.014 & & \\
\hline Total & 279702.089 & 54 & & & \\
\hline Corrected Total & 28842.188 & 53 & & & \\
\hline
\end{tabular}

TABLE 4 - Analysis of variance results for powdery mildew infection incidence.

\begin{tabular}{|c|c|c|c|c|c|}
\hline Phytotron & N & Mean Rank & Chi-Square & df & Asymp. Sig. \\
\hline 1 & 18 & 14.25 & & & \\
2 & 18 & 38.69 & & & \\
3 & 18 & 29.56 & 22.192 & 2 & $0.000^{*}$ \\
\hline
\end{tabular}

TABLE 5 - Kruskal-Wallis test results for powdery mildew infection incidence.

\begin{tabular}{|c|c|c|c|}
\hline \multirow{2}{*}{ Phytotron } & \multirow{2}{*}{$\mathbf{N}$} & \multicolumn{2}{|c|}{ Subset } \\
\cline { 3 - 4 } & & 1 & 2 \\
\hline Elevated T and $\mathrm{CO}_{2}$ & 18 & 47.25 & 73.42 \\
Ambient & 18 & & 83.80 \\
Elevated $\mathrm{CO}_{2}$ & 18 & & .089 \\
\hline Sig. & & 1.000 & \\
\hline
\end{tabular}

TABLE $6-$ S-N-K test results for powdery mildew infection incidence. 


\begin{tabular}{|c|c|c|c|}
\hline \multirow{2}{*}{ Phytotron } & \multirow{2}{*}{} & \multicolumn{2}{|c|}{ Subset } \\
\cline { 3 - 4 } & & 1 & 2 \\
\hline Elevated $\mathrm{T}$ and $\mathrm{CO}_{2}$ & 18 & 7.81 & 16.33 \\
Elevated $\mathrm{CO}_{2}$ & 18 & & 16.98 \\
Ambient & 18 & & .760 \\
\hline Sig. & & 1.000 & \\
\hline
\end{tabular}

TABLE 7 - S-N-K test results for powdery mildew severity incidence.

\begin{tabular}{|c|c|c|c|c|c|}
\hline Source & Type III Sum of Squares & df & Mean Square & $\mathbf{F}$ & Sig. \\
\hline Corrected Model & 17138.63 & 5 & 3427.73 & 12.44 & .001 \\
\hline Intercept & 135271.1 & 1 & 135271.1 & 491.03 & .000 \\
\hline Phytotron & 10566.81 & 2 & 5283.41 & 19.18 & $.000 *$ \\
\hline Cultivar & 5885.45 & 1 & 5885.45 & 21.36 & .000 \\
\hline Phytotron * Cultivar & 686.37 & 2 & 343.19 & 1.24 & .297 \\
\hline Error & 13223.17 & 48 & 275.48 & & \\
\hline Total & 165632.9 & 54 & & & \\
\hline Corrected Total & 30361.8 & 53 & & & \\
\hline
\end{tabular}

TABLE 8 - Analysis of variance results for downy mildew infection severity.

\subsubsection{Downy mildew}

Two trials were carried out. The second trial confirmed the results observed during the first one and data analysis refers to the first trial.

The analysis of variance shows differences between environmental conditions in both incidence (mean percentage of leaves infected) and severity (mean percentage of leaf area infected) of downy mildew infection. Differences between cultivar were also detected (Tab. 8 and 9). Levene's test showed that the assumption about homogeneity of error variances among groups is violated for this variable. Thus, the Kruskal-Wallis test was used to confirm the analysis of variance results (Tab. 10). In order to un- derstand how environmental conditions could affect pathogen development a Student-Newman-Keuls was applied to find out differences between data coming from differently set-up phytotrons (Tab. 11 and 12).

A combination of increasing temperature and carbon dioxide concentration increased both the severity and incidence of downy mildew. Disease infection in "Elevated $\mathrm{CO}_{2}$ " was higher than in "Ambient" environmental conditions, while disease severity in "Elevated $\mathrm{CO}_{2}$ " was similar to "Ambient" environmental conditions. It seems that plants in "Elevated $\mathrm{CO}_{2}$ " conditions were more disease-susceptible.

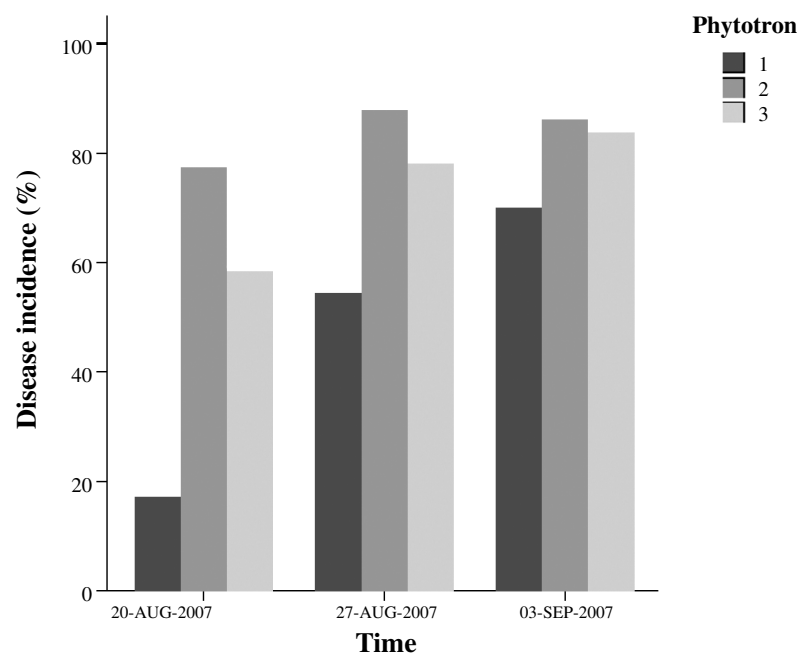

Fig. 3 - Disease incidence trend in percentage.

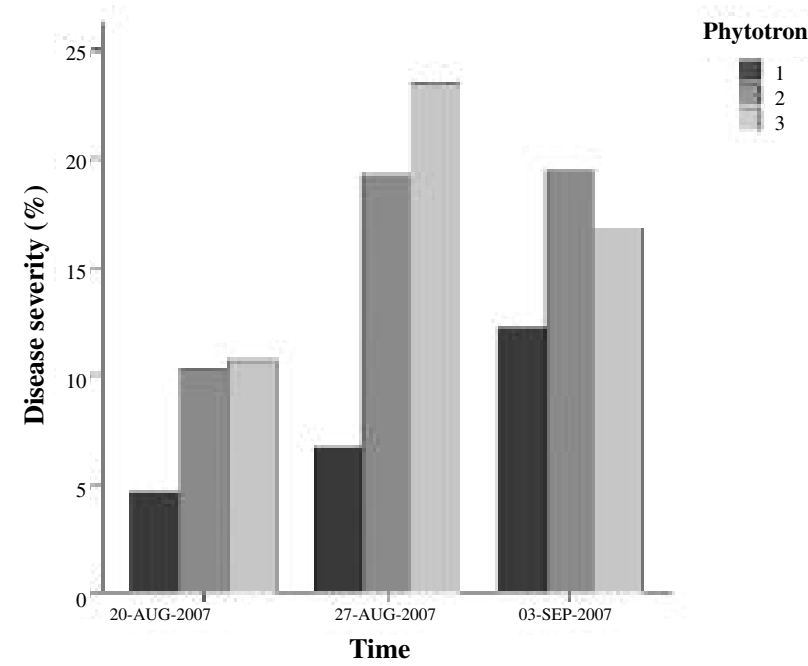

Fig. 4 - Disease severity trend in percentage. 


\begin{tabular}{|c|c|c|c|c|c|}
\hline Source & Type III Sum of Squares & df & Mean Square & $\mathbf{F}$ & Sig. \\
\hline Corrected Model & 2372.19 & 5 & 474.44 & 8.62 & .000 \\
\hline Intercept & 4011.06 & 1 & 4011.06 & 72.87 & .000 \\
\hline Phytotron & 695.89 & 2 & 347.94 & 6.32 & $.004 *$ \\
\hline Cultivar & 1234.39 & 1 & 1234.39 & 22.42 & .000 \\
\hline Phytotron * Cultivar & 441.92 & 2 & 220.96 & 4.01 & .024 \\
\hline Error & 2642.17 & 48 & 55.05 & & \\
\hline Total & 9025.42 & 54 & & & \\
\hline Corrected Total & 5014.36 & 53 & & & \\
\hline
\end{tabular}

TABLE 9 - Analysis of variance results for downy mildew infection incidence.

\begin{tabular}{|c|c|c|c|c|c|}
\hline Phytotron & N & Mean Rank & Chi-Square & df & Asymp. Sig. \\
\hline 1 & 18 & 39.42 & & & \\
2 & 18 & 25.78 & & & \\
3 & 18 & 17.31 & 18.112 & 2 & $0.000^{*}$ \\
\hline
\end{tabular}

TABLE $\quad 10-\quad$ Kruskal-Wallis test results for downy mildew infection incidence.

\begin{tabular}{|c|c|c|c|c|}
\hline \multirow{2}{*}{ Phytotron } & \multirow{2}{*}{$\mathbf{N}$} & \multicolumn{3}{|c|}{ Subset } \\
\cline { 3 - 5 } & & 1 & 2 & 3 \\
\hline Elevated T and $\mathrm{CO}_{2}$ & 18 & 68.44 & & \\
Elevated $\mathrm{CO}_{2}$ & 18 & & 47.16 & 34.54 \\
Ambient & 18 & & & 1.000 \\
\hline Sig. & & 1.000 & 1.000 & \\
\hline
\end{tabular}

TABLE $11-\quad$ S-N-K test results for downy mildew infection incidence.

\begin{tabular}{|c|c|c|c|}
\hline \multirow{2}{*}{ Phytotron } & \multirow{2}{*}{$\mathbf{N}$} & \multicolumn{2}{|c|}{ Subset } \\
\cline { 3 - 4 } & & 1 & 2 \\
\hline Elevated $\mathrm{T}$ and $\mathrm{CO}_{2}$ & 18 & 13.05 & 8.54 \\
Elevated $\mathrm{CO}_{2}$ & 18 & 8.54 & 4.26 \\
Ambient & 18 & & 0.074 \\
\hline Sig. & & 0.090 & \\
\hline
\end{tabular}

TABLE 12 - S-N-K test results for downy mildew severity incidence.

\section{Conclusions}

Phytotrons are innovative equipment where it is possible to maintain all the environmental parameters important for disease development constantly and completely under control.

The opportunity of reproducing different climatic and meteorological conditions for experimental purposes can be very useful in simulating climatic scenarios and monitoring plants, pathogens and plantpathogen interactions responses to these different conditions. In fact, because of the lack of resources and proper facilities like phytotrons, climate change effects have until now been mainly studied on crops grown in open field [Bernacchi 2006; Ainsworth 2002].

In particular, the possibility of mimicking future climatic projections can lead to a consistent assessment of climate change impact on agroecosystems [Clifford 2000; Cheng 2006].

Phytotrons experimental activities offer a wide range of operational and cognitive tools, whose application could be extremely useful not only for researchers but also for farmers, cooperative organiza- 
tions and public administrations. For example, several environmental scenarios can be simulated in order to analyze the activity of plants developing inside the chambers under different environmental conditions sets by measuring physiological parameters.

From a plant pathological point of view, the use of phytotrons provides useful information concerning pathogen development and plant-pathogen interactions under different environmental conditions. In particular, for crops of strategic economic importance, information about the impact of pathogen development on both yield and quality can be obtained.

These phytotrons, specifically developed for research purposes in plant pathology, responded generally well to our expectations. Our reasons to develop walk-in climatic chamber optimized for studying plant-pathogens interactions and climate effects on plant diseases have been met. The internal space in each phytotron is divided in two sectors, in order to maintain as constant as possible the conditions above and below ground, minimizing the potential, negative interactions related to $\mathrm{CO}_{2}$ and water vapour. It is possible to collect the drainage water and also to calculate a $\mathrm{CO}_{2}$ balance according to the foliar transpiration and the water balance. Indeed, the large numbers of parameters that can be monitored represents an interesting opportunity and a useful tool for a wide range of applications in several research fields. Moreover, experiments carried out in these kinds of chambers can be compared to field data, not only in a qualitative way, but also in a quantitative one [Hsiao 2000; Moot 1996].

This approach can provide an opportunity to further develop the application of laboratory techniques for the analysis and forecast of plants activity in comparable environmental conditions.

\section{Acknowledgments}

Work supported by the Italian Ministry for Environment, Land and Sea and by Piedmont Region (CIPE) within the project "Adoption of a multisciplinary approach to study the grapevine agroecosystem: analysis of biotic and abiotic factors able to influence yield and quality" (MASGRAPE).

\section{References}

Ainsworth E.A., Davey P.A., Bernacchi C.J., Dermody O.C., Heaton E.A., Moore D.J., Morgan P.B., Naidu S.L., Yoo Ra H., Zhu X., Curtis P.S., Long S.P., A metaanalysis of elevated $\mathrm{CO}_{2}$ effects on soybean (Glycine max) physiology, growth and yield. Global Change Biology, 2002, 8(8), 695-709.

Bernacchi C.J., Leakey A.D.B., Heady L., Morgan P.B., Dohleman F.G., McGrath J.M., Gillespie K.M., Wittig V.E., Rogers A., Long S.P., Ort D.R., Hourly and seasonal variation in photosynthesis and stomatal conductance of soybean grown at future $\mathrm{CO}_{2}$ and ozone con- centrations for 3 years under fully open-air field conditions. Plant, Cell \& Environment, 2006, 29(11), 20772090.

Ceulemans R., Mousseau M., Effects of elevated atmospheric $\mathrm{CO}_{2}$ on woody plants. New Phytologist, 1994, $146,415-425$.

Chakraborty S., von Tiedemann A., Teng P.S., Climate change: potential impact on plant diseases. Environmental Pollution, 2000, 108(3), 317-326.

Cheng W., Yagi K., Sakai H., Kobayashi K., Effects of Elevated Atmospheric $\mathrm{CO}_{2}$ Concentrations on $\mathrm{CH}_{4}$ and $\mathrm{N}_{2} \mathrm{O}$ Emission from Rice Soil: An Experiment in Controlledenvironment Chambers. Biogeochemistry, 2006, 77(3) 351-373.

Cherukuri D.P., Gupta S.K., Charpe A., Koul S., Prabhu K.V., Singh R.B., Rizwanul Haq Q.M., Molecular mapping of Aegilops speltoides derived leaf rust resistance gene $L r 28$ in wheat. Euphytica, 2005, 143, 19-26.

Clifford S.C., Stronach I.M., Black C.R., Singleton-Jones P.R., Azam-Ali S.N., Crout N.M.J., Effects of elevated $\mathrm{CO}_{2}$, drought and temperature on the water relations and gas exchange of groundnut (Arachis hypogaea) stands grown in controlled environment glasshouses. Physiologia Plantarum, 2000, 110(1), 78-88.

Coakley S.M., Scherm H., Chakraborty S., Climate change and plant disease management. Annual Review of Phytopathology, 1999, 37, 399-426.

Curtis P.S., Wang X., A meta-analysis of elevated CO2 effects on woody plant mass, form, and physiology. Oecologia, 1998, 113, 299-313.

Dormann C.F., Wal R., van der Woodin S.J., Neighbour identity modifies effects of elevated temperature on plant performance in the High Arctic. Global Change Biology, 2004, 10(9), 1587-1598.

Espigares T., Peco B., Mediterranean pasture dynamics: the role of germination. Journal of Vegetation Science. 4(2), 189-194. $34^{\text {th }}$ IAVS Symposium on mechanisms in vegetation dynamics, 1993, Eger, Hungary, 26-30 August 1991.

Fuhrer J., Agroecosystem responses to combinations of elevated $\mathrm{CO}_{2}$, ozone and global climate change. Agriculture, Ecosystems and Environment, 2003, 97, 1-20.

Fukui K., Effects of temperature on growth and dry matter accumulation in mulberry saplings. Plant Production Science, 2004a, 3(4), 404-409.

Fukui K., Modeling of shoot elongation and leaf appearance in potted mulberry. Plant Production Science, 2004b, 3(4), 410-416.

Fukui K., Modeling the interactive effect of the photoperiod and temperature on shoot elongation of mulberry. Plant Production Science, 2004c, 7(2), 224-229.

Garrett K.A., Dendy S.P., Frank E.E., Rouse M.N., Travers S.E., Climate change effects on plant disease: genomes to ecosystems. Annual Review of Phytopathology, 2006, 44, 489-509.

Gorissen A., Kuikman P.J., van de Beek H., Carbon allocation and water use in juvenile Douglas fir under elevated $\mathrm{CO}_{2}$. New Phytologist, 1995, 129(2), 275-282.

Grams T.E.E., Anegg S., Häberle K.H., Langebartels C., Matyssek R., Interactions of chronic exposure to elevated $\mathrm{CO}_{2}$ and $\mathrm{O}_{3}$ levels in the photosynthetic light and dark reactions of European beech (Fagus sylvatica). New Phytologist, 1999, 144(1), 95-107.

Grote D., Claussen W., Severity of root rot on tomato plants caused by Phytophthora nicotianae under nutrient- and light-stress. Plant Pathology, 2001, 50, 702-707. 
Gutierrez W.A., Shew H.D., Factors that affect development of collar rot on tobaccoseedlings grown in greenhouses. Plant Disease, 2000, 84, 1076-1080.

Harnos N., Veisz O., Tischner T., Effects of elevated $\mathrm{CO}_{2}$ concentration on the development and yield components of cereals. Acta Agronomica Hungarica, 1998, 46(1), 1524.

Hsiao T.C., Xu L.K., Predicting water use efficiency of crops. Acta Horticulturae, 2000, 537, 199-206.

IPCC. Climate Change 2007: The Physical Science Basis. Summary for Policymakers. Contribution of Working Group I to the Fourth Assessment Report of the Intergovernmental Panel on Climate Change. http://www. ipcc.ch/SPM2feb07.pdf

Kim S.E., Okubo H., Control of growth habit in determinate lablab bean (Lablab purpureus) by temperature and photoperiod. Scientia Horticulturae, 1995, 61, (3/4), 147-155.

Liu X.P., Grams T.E.E., Matyssek R., Rennenberg H., Effects of elevated $p \mathrm{CO}_{2}$ and/or $p \mathrm{O}_{3}$ on $\mathrm{C}-, \mathrm{N}-$, and $\mathrm{S}$ metabolites in the leaves of juvenile beech and spruce differ between trees grown in monoculture and mixed culture. Plant physiology and Biochemistry, 2005, 43(2), 147-154.

Luedemann G., Matyssek R., Winkler J.B., Grams T. E.E., Contrasting ozone $\mathrm{x}$ pathogen interaction as mediated through competition between juvenile European beech (Fagus sylvatica) and Norway spruce (Picea abies). Plant Soil, 2009, 323, 47-60.

Marek M.V., Kalina J., Matouškoá M., Response of photosynthetic carbon assimilation of Norway spruce exposed to long-term elevation of $\mathrm{CO}_{2}$ concentration. Photosynthetica, 1995, 31, 209-220.

Matyssek R., Innes J.L., Ozone- a risk factor for trees and forests in Europe?. Water Air Soil Pollution, 1999, 116, 199-226.

McElrone A.J., Reid C.D., Hoye K.A., Hart E., Jackson R.B., Elevated $\mathrm{CO}_{2}$ reduces disease incidence and severity of a red maple fungal pathogen via changes in host physiology and leaf chemistry. Global change biology, 2005, 11(10), 1828-1836.

Moot J., Henderson A.L., Porter J.R., Semenov M., Temperature, $\mathrm{CO}_{2}$ and the growth and development of wheat: changes in mean and variability of growing conditions. Climatic change, 1996, 33(3), 351-368.

Norby R.J., Edwards N.T., Riggs J.S., Abner C.H., Wullschleger S.D., Gunderson C.A., Temperature-controlled open-top chambers for global change research research. Global Change Biology, 1997, 3, 259-267.

Norby R.J., Wullschleger S.D., Gunderson C.A., Johnson D.W., Ceulemans R., Tree responses to rising $\mathrm{CO}_{2}$ in field experiments: implications for future forests. Plant Cell Environment, 1999, 22, 683-714.

Nunn A.J., Kozovits A.R., Reiter I.M., Heerdt C., Leuchner M., Lutz C., Liu X., Lo W.M., Winkler J.B., Grams T.E.E., Haberle K.H., Werner H., Fabian P., Rennenberg H., Matyssek R., Comparison of ozone uptake and sensitivity between a phytotron study with young beech and a field experiment with adult beech (Fagus sylvatica). Environmental Pollution, 2005, 137(3), 494-506.

Percy K.E., Awmack C.S., Lindroth R.L., Altered performance of forest pests under atmospheres enriched by $\mathrm{CO}_{2}$ and $\mathrm{O}_{3}$. Nature, 2002, 420, 403-407.

Pritsch K., Luedemann G., Matyssek R., Hartmann A., Schloter M., Scherb H., Grams T.E.E., Mycorrhizosphere responsiveness to atmospheric ozone and inocula- tion with Phytophthora citricola in a phytotrone experiment with spruce beech mixed cultures. Plant Biology, 2005, 7, 718-727.

Reignault P.H., Cogan A., Muchembled J., Sahraoui A.L.H., Durand R., Sancholle M., Trehalose induces resistance to powdery mildew in wheat. New Phytologist, 2001, 149(3), 519-529.

Rosenfeld H.J., The influence of climate on sensory quality and chemical composition of carrots for fresh consume and industrial use. Acta Horticulturae, 1998, 476, 69-76.

Runion G.B., Climate change and plant pathosystems - future disease prevention starts here. New Phytologist, 2003, 159, 531-533.

Schmadel-Hagebolling H.E., Engel C., Schmitt V., Wild A., The combined effects of $\mathrm{CO}_{2}$ ozone and drought on rubisco and nitrogen metabolism of young oak trees (Quercus petraea). A phytotron study. Chemosphere, 1998, 36, 789-794.

Salinari F., Giosuè S., Tubiello F.N., Rettori A., Rossi V., Spanna F., Rosenzweig C., Gullino M.L., Downy mildew (Plasmopara viticola) epidemics on grapevine under climate change. Global Change Biology, 2006, 12(7), 1299-1307.

Sasaki H., Fukuyama M., Onoue T., Suyama T., Shoji A., Effects of increasing $\mathrm{CO}_{2}$ concentration and leaf temperature on the photosynthesis of tall fescue (Festuca arundinacea Schreb.). Grassland Science, 2002, 48(1), 12-16.

Senft D., FACE-ing the future. Agricultural Research, 1995, 43, 4-6.

Tahir I.S.A., Nakata N., Remobilization of nitrogen and carbohydrate from stems of bread wheat in response to heat stress during grain filling. Journal of Agronomy and Crop Science, 2005, 191(2), 106-115.

Tani A., Nishiura Y., Kiyota M., Murase H., Honami N., Aiga I., Performance of a centrifugal phytotron. Advance Space Research, 1996, 18, 251-254.

Thiel S., Dohring T., Kofferlein M., Kosak A., Martin P., Seidlitz H.K., A phytotron for plant stress research: How far can artificial lighting compare to natural sunlight? Journal of Plant Physiology, 1996, 148, 456-463.

Uprety D.C., Carbon dioxide enrichment technology: Open top chambers a new tool for global climate research. Journal of Scientific and Industrial Research, 1998, 57, 266-270.

Yazaki K., Ishida S., Kawagishi T., Fukatsu E., Maruyama Y., Kitao M., Tobita H., Koike T., Funada R., Effects of elevated $\mathrm{CO}_{2}$ concentration on growth, annual ring structure and photosynthesis in Larix kaempferi seedlings. Tree Physiology, 2004, 24, 951-959.

\section{SUMMARY}

The Intergovernmental Panel on Climate Change in its recent fourth assessment report predicts that, because of higher concentrations of greenhouse gases in the atmosphere, until 2100 the global mean temperature would rise between 0.6 and $4^{\circ} \mathrm{C}$, in combination with changes in precipitation and an increased frequency of extreme weather events. Despite this trend, the extent and mechanisms through which elevated $\mathrm{CO}_{2}$ affects plant diseases remain uncertain. Increases in $\mathrm{CO}_{2}$ and temperatures are also expected to induce complex effects on plant pathogens. Although re- 
search on the effects of climate change continues to be limited, new tools are permitting to study the effects of climate variables on infection rates in the case of some pathosystems. The shortage of critical epidemiological data on individual plant diseases needs to be addressed using experimental approaches. A useful tool for such types of studies is represented by phytotrons. Hereby, a new phytotron typology, built with the specific aim of studying the effect of climate change on plant disease, is described. Beginning from a general plant overview, key mechanical and electrical systems are described (i.e. air temperature and relative humidity control, lighting and $\mathrm{CO}_{2}$ control system etc.) as environmental parameters and operation cycle are summarized. In particular both parameters which could be set and monitored and those measured and stored are reported. After a suitable testing period, several operation cycles were performed in order to assess the control system's stability and to optimize the management of all systems involved and the first experimental trials were carried out. The effect of three different simulated climatic conditions: $450 \mathrm{ppm}$ of $\mathrm{CO}_{2}$ with standard temperature (ranging from 18 to $24^{\circ} \mathrm{C}$ or 18 to $\left.26^{\circ} \mathrm{C}\right)$, elevated $\mathrm{CO}_{2}(800 \mathrm{ppm})$ with standard temperature and elevated $\mathrm{CO}_{2}(800 \mathrm{ppm})$ with elevated temperature $\left(4^{\circ} \mathrm{C}\right.$ higher than standard) on the development of grape powdery and downy mildew were tested.

Keywords: phytotron, controlled environment, climate change, grapevine, powdery mildew; downy mildew. 


\section{Report on the $39^{\text {th }}$ International Symposium \\ Actual Tasks on Agricultural Engineering 22-25 February 2011, Opatija, Croatia}

The $39^{\text {th }}$ International Symposium Actual Tasks on Agricultural Engineering was held on $22^{\text {nd }}-25^{\text {th }}$ February 2011 in Grand Hotel "Adriatic" Opatija, Republic of Croatia. The principle Organiser, Agricultural Engineering Department, Faculty of Agriculture, University of Zagreb was supported by the following frameworks: Department of Agricultural Engineering, Faculty of Agriculture, University J.J. Strossmayer, Osijek, Department of Biosystems Engineering, Faculty of Agriculture, University of Maribor (Slovenia), Agricultural Institute of Slovenia, Hungarian Institute of Agricultural Engineering Gödöllö and Croatian Agricultural Engineering Society. In addition, CIGR, EurAgEng, AAAE and the Association of Agricultural Engineers of South Eastern Europe (AAESEE) bestowed their support and endorsement on the Event.

This year 75 participants from 10 countries attended the Symposium. It consisted of an Opening Session and six Topic Sessions covering all the broad subject-areas that fall under the scope of Agricultural Engineering. At the Opening Session prof. dr. Edi Maletic, vice-dean of the Faculty of Agriculture, University of Zagreb, delivered his speech emphasising the importance of the Event and its long tradition. Prof. Daniele De Wrachien brought the greetings of EurAgEnd and CIGR and the Convenor, Prof. Silvio Kosutic ended the Opening Session with the greetings of the Croatian Society of Agricultural Engineering to the audience. A number of lectures followed, among which are worth mentioning: "Cab damping device evaluation on tractor vibration transmission and operator comfort using four-poster test rig" presented by BEng Carlo Bisaglia from Italy, "Mathematical models for flood and debris flow routing" given by prof. dr. Daniele De Wrachien from Italy, "About the noise energy conversion from agricultural tractors engine" featured by prof. dr Nicolae Filip from Romania, "Monitoring and assessing the performance of agricultural biogas plants" delivered by Mathias Effenberger from Germany and Djordje Djatkov from Serbia, "Sizing small wind generators according to probabilistic information on wind conditions" proposed by Kaupo Toom from Estonia, "Drying investigation of hull-less pumpkin kernels (Cucurbita Pepo L.) in batch driers" introduced by prof.dr. Milan Martinov from Serbia, "Development on the field of agricultural biogas plants in Slovenia" highlighted by MSc. Tomaz Poje from Slovenia and "Technology of post-harvest residues cutting" presented by dr.sc. Viktor Jejcic from Slovenia. In the Topic Sessions, each starting with a review report, 42 papers were discussed, in oral presentation. At the Closing Session the Convenor emphasised the role of EurAgEng and CIGR in the ecologically sustainable development of agriculture and in the preservation of the rural cultural heritage within the East-European countries. Participants were given printed copies of the Proceedings consisting in Volumes of 472 pages ,containing 48 papers. Papers from the Proceedings have been indexed in database ISI Proceedings since 1997. Maziva Zagreb d.d.-INA group (national petrol company) presented its new palette of bio-degradable oils emphasising the progress made in keeping pace with well known worldwide competitors. Other companies like Same-Deutz Fahr, Agco, Trimble and Hardy highlighted their current programmes by means of video and oral presentations during afternoon Sessions.

Information regarding the $40^{\text {th }}$ Symposium in the year 2012 will soon be available at the web site: http://atae.agr.gr

Prof. Silvio Kosutic, Convenor of the Symposium Prof. Daniele De Wrachien, Past President of EurAgEng 